\title{
Urban planning from a top-down to a bottom-up model: the case of Mexicali, Mexico
}

\author{
R. Rojas-Caldelas ${ }^{1}$, A. Ranfla-Gónzalez ${ }^{2}$, C. Peña-Salmón ${ }^{1}$, \\ O. Leyva-Camacho ${ }^{1} \&$ E. Corona-Zambrano ${ }^{1}$ \\ ${ }^{I}$ Faculty of Architecture and Design, \\ Autonomous University of Baja California, Mexico \\ ${ }^{2}$ Institute of Social Research, \\ Autonomous University of Baja California, Mexico
}

\begin{abstract}
Urban development planning in Mexico begins with the publication of the General Law on Human Settlements in 1976, which sets up several planning instruments to regulate land use and urban development at state, municipal and urban level. Urban planning in the late seventies was characterized by being made by the state, with a rational approach, enforced from a top-down perspective, supported by planning guides made by professional planners and public consultation at the end of plan making. Current urban planning has been modifying its methods to a strategic and communicative model, a bottom-up perspective. The state has been playing a regulatory function and the participation of stakeholders has become a central issue on urban development planning and management. Therefore, this study has two main purposes: firstly, to analyse the evolution of urban planning in more than four decades and; secondly, to present Mexicali city as a good practice case study of the application of the bottom-up planning model. This project shows the changes that urban development has undertaken throughout a strategic planning view, oriented to long term perspective, organized and undertaken by society with collaborative work coming from different sectors: government, private and nongovernmental organizations. The methodology was based on the Logical Framework Approach, working along nine months with thematic groups. The results were integrated in a project portfolio, to be implemented in the short, middle and long term. Lastly, findings show successes in urban development planning and obstacles that society has faced in order to implement development projects within a political municipal agenda.

Keywords: urban planning, community planning, communicative planning, strategic planning.
\end{abstract}




\section{Introduction}

The planning of human settlements in Mexico begins with the publication of the General Law on Human Settlements in 1976, when the first world summit on human settlements was held in Vancouver, Canada. Thus the urban development planning was institutionalized and executed at a federal level [1] (Federal Official Gazette, 1976). At that time, the state had an important role in the stewardship of the economy and providing educational, health, roads, transportation, housing, and energy infrastructure and production, among other things. This outlook has been modified over almost 50 years by demographic, economic, social, institutional, environmental processes with different manifestations of population concentration and distribution in the territory. The aforementioned dynamic changes its trend in Mexico starting from the 1970 s, as indicated by Mendoza and Tapia, i.e., $57.8 \%$ of the population had urban residence in 1970 and $77.5 \%$ in 2010. Sobrino [2], on the other hand, states that the National Urban System presented a restructuring from 1980 to 2010: "In absolute terms, the largest increase occurred in small urban areas, while in relative terms the most significant change was in population areas having over a million inhabitants, where the quantity almost tripled."

Changes in planning and managing urban development have also been influenced by different dynamics coming from theoretical approaches, legal regulation, practical context and international policies of different kinds. For this research those of greatest impact have derived from international summits on human settlements and the environment that were held during the 1970s. Such summits promoted the creation of legal frameworks and policies related to international funding agencies for project development. Therefore, the purpose of this paper is to present the conceptual framework that has guided urban and regional development planning, as well as the legal changes that have been implemented for its operation, and to examine such changes from a top-down to a bottom-up scheme through the case study of the "Mexicali, City of Great Vision" project.

\section{Approaches to development planning}

The reference framework of development planning arose during the 1950s and was consolidated as a positivist current applied to various disciplines, among them regional and urban development and the so-called Rational-Systemic approach $[3,4]$ during the 1960s and 1970s (see Figure 1). This current is found in a context of mixed economy, where planning was centralized in the state and was required by international funding agencies for project development. This planning was based on the scientific method and a systemic approach applied to the analysis of cities and its various subsystems.

The results of the process were directed to the selection of an optimal proposal that would show lower costs and cover the outlined purposes, where the decision was centralized, the participation of the population was practically null and the planner played a purely "technical" role, this field of knowledge being dominated by economists, architects and planners. 


\section{Normative and Rational-Systemic \\ 1960-1985}

\footnotetext{
$\checkmark \quad$ Development planning required by international funding agencies.

$\checkmark \quad$ Institutional planning developed in a context of mixed economy.

$\checkmark \quad$ Intervention of the state as planner and manager of national and regional development.

$\checkmark \quad$ Planning for economic, social and political development.

$\checkmark \quad$ Planning based on the scientific method.

$\checkmark \quad$ Linear process.

$\checkmark \quad$ Simple system with interrelated subsystems.

$\checkmark \quad$ Analysis of multiple options and selecting the optimal or efficient one.

$\checkmark \quad$ Centralized decision making by the responsible party.

$\checkmark$ Participation of various experts or planning "technicians".

$\checkmark \quad$ No other social actors are involved.

$\checkmark \quad$ Short, medium and long term vision.
}

\begin{tabular}{ll}
\hline & \multicolumn{1}{c}{ Neoliberal Strategic Planning } \\
& \multicolumn{1}{c}{$\mathbf{1 9 8 0 - 2 0 0 0}$} \\
$\checkmark$ & Transition of mixed economy to free market. \\
$\checkmark$ & Theduced intervention of the state in the economy (producer and employer). \\
$\checkmark$ & Alliance between Conservative and Liberal political forces. \\
$\checkmark$ & Control over efficient land use and regulation. \\
$\checkmark$ & Openness to planning outside of the state. \\
$\checkmark$ & Strengthening the Private Sector and NGOs. \\
$\checkmark$ & Privatization processes. \\
$\checkmark$ & Administrative decentralization. \\
$\checkmark$ & Management planning procedure applied to public administration. \\
$\checkmark$ & Flexible adjustment planning in time and nonlinear. \\
$\checkmark$ & Planning based on results, efficiency and effectiveness in fulfilling goals. \\
$\checkmark$ & Monitoring and evaluation systems instrumentation. \\
$\checkmark$ & Long-term planning focused on priorities. \\
$\checkmark$ & Planning that integrates non-expert opinions. \\
$\checkmark$ & The planner has a role as technical facilitator in the process. \\
$\checkmark$ & Incorporation of human development and sustainable development. \\
& \\
$\checkmark$ &
\end{tabular}

Figure 1: Approaches to development planning.

The next important moment for planning development was set out between the 1980 s and 1990s, when the transition towards a neoliberal economic model takes place. It is then that the power of the state is reduced in its role as employer and producer, keeping basically regulatory functions, to promote efficient land use and 
planning at different scales [4]. As a result of the economic model, a series of reforms to the legal framework were enforced, strengthening the decentralization of administrative functions, commercial treaties, privatization, openness to participation by the private sector and NGOs in planning and territorial action management, and the incorporation of sustainable human development in the overall planning framework. The modifications now respond to a management planning model applied to public administration, which dominates the longterm planning, focusing on priorities, efficiency assessment criteria and effectiveness of results produced by the strategic planning model. During this time the incorporation of the paradigms of sustainable development and human development is also present, as well as the strengthening of social participation throughout the process as a counterweight to expert opinions; the planner is no longer seen as a sheer expert or "technician", but as a facilitator to achieve consensus.

Finally, the model of collaborative communicative planning is identified [4]. Although created in the 1990s, it appears most clearly from 2000 to date, in a context where the state-market relationship is being strengthened, with the promotion of alliances between the public, private and social sectors towards the construction of desirable futures through the public agenda, the transition from vertical planning to governance is also put forward. The model is based on strategic, but it introduces two concepts: communicative rationality, directed to the creation of an objectivity based on the agreement between individuals, supplemented by a second concept, communicative action, regarding the process through which participants reach intersubjective understanding by the coordination of discussion and socialization, debates where the integration of objective knowledge and narrative is favored [5-8]. Planning is participatory, bottom-up, as different interest groups work together in solving their problems through communication strategies, and the planner acts as a mediator to reach agreed decisions.

\section{Evolution of the legal framework for urban development and the operation of institutions}

In terms of urban development, Mexican law, according to De las Fuentes [9], had been characterized, from its origins to the early 20th century, by regulating the urban aspects in a partial or fragmented way. The 1917 Constitution established the first regulations to make laws on migration, sanitation and human settlements. Subsequently, the Law on General Planning of the Republic was established in 1930, including aspects and studies on regional and urban planning, network of roads and use of resources. In 1953, the Law on State Secretariats and Administrative Departments is passed to plan works for regional promotion and development; but it was not until 1976, with the constitutional reforms to Article 27 (land ownership), Article 115 (States and Municipalities), and the enactment of the General Law on Human Settlements, that a comprehensive insight in the planning of urban development was introduced. 
Since 1976, four periods can be set at the federal level as decisive in marking the approach to urban planning: 1976 to 1982,1982 to 1992,1992 to 2013 , and 2013 to the present. At a local level, five periods can be identified in the planning and management of urban development, from the state leadership to the initiative of social organizations: 1973-1984, 1984-1992, 1992-1999, 1999-2012 and 2012-2014 (Figure 2).

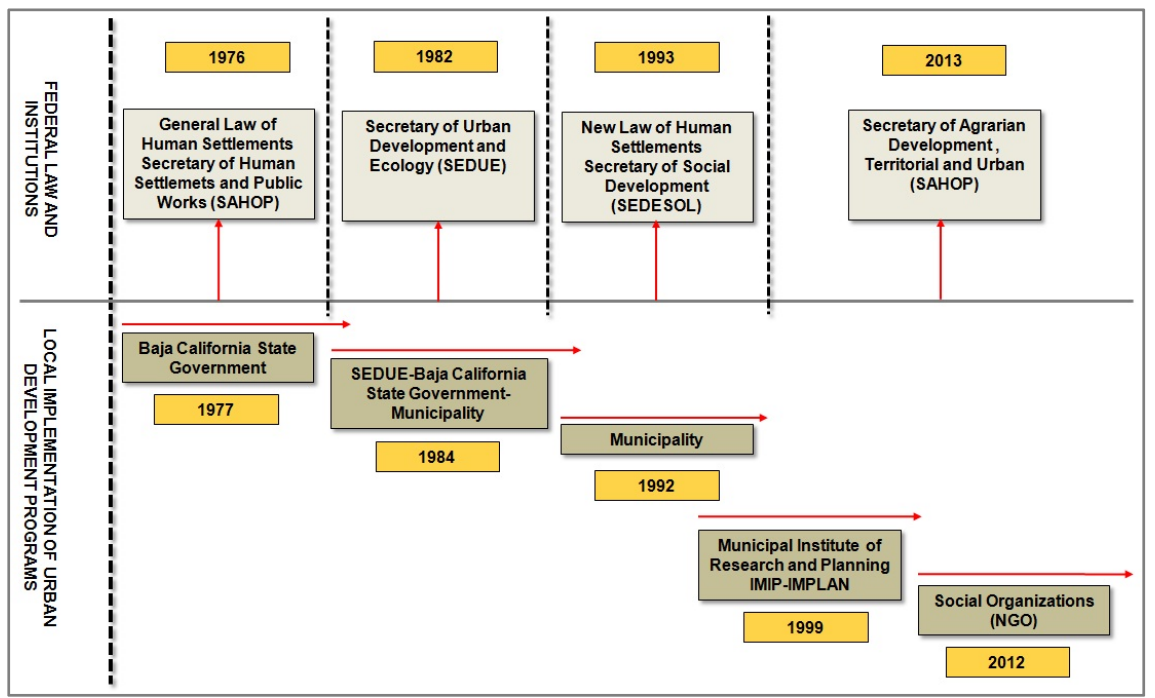

Figure 2: Timeline, planning legal framework.

At the federal level, during the 1976-1982 period, urban planning is formalized as a public service with the enactment in 1976 of the General Law on Human Settlements (Ley General de Asentamientos Humanos, LGAH), which establishes the National Planning System for Urban Development and the attributions of the three levels of government (federal, state and municipal), and the public participation in urban development planning. The Ministry of Human Settlements and Public Works (Secretaría de Asentamientos Humanos y Obras Públicas, SAHOP) was created in 1977 to perform this function $[9,10]$.

During 1982-1992, several amendments were made to the LGAH, mainly: the substitution of the National Plan of Urban Development for the Sectorial Program of Urban Development, just as State Plans were substituted by State Programs of Urban Development. In 1983, the Ministry of Urban Development and Ecology (Secretaría de Desarrollo Urbano y Ecología, SEDUE) is created to integrate the functions of urban development planning and environmental protection.

During the 1992-2013 period, the Ministry of Social Development (Secretaria de Desarrollo Social, SEDESOL) is created in 1992 to replace the Ministry of Urban Development and Ecology, integrating the functions of urban development and social development; attributions in ecological matters were assigned to the National Institute of Ecology and to the Federal Attorney for Environmental 
Protection, as decentralized bodies with technical and operational autonomy. Also in 1993, important amendments to the LGAH were made in relation to citizen's participation, private participation, increasing management capacity of local authorities regarding urban and ecological matters $[9,10]$.

As of January 2, 2013, the Ministry of Agrarian, Territorial and Urban Development (Secretaría de Desarrollo Agrario, Territorial y Urbano, SEDATU) is created, leaving the function of social development to SEDESOL and concentrating three key sectors to promote the development of the nation: the country side, urban zones and housing. Among the functions of urban development are impulsing the regulation of the national territory; planning and projecting the proper population distribution and land regulation in population centers, cities and metropolitan areas, under sustainable development criteria [11].

In the 1973-1984 period, "Regulatory Plans" were prepared in the 1970s by the Baja California State Government [12], in relation to the state agencies operation to prepare Urban Development Municipal Programs and Urban Development of Population Center Programs (PDUCP, by its initials in Spanish).

During the 1980s, the development of the PDUCPs of the major municipal centers was by the concurrence of the SEDUE, SAHOPE and the respective municipality.

In the 1990s, after the transfer of state functions to municipalities regarding the cadaster, urban planning and control, the municipalities created in their administrative structure an agency responsible for urban planning that prepares the municipal programs of urban development and the PDUCPs.

By the late 1990s and early 2000s, urban planning was done through public bodies decentralized from the municipality, with legal personality and assets of their own, and with technical autonomy, through which urban development policies, plans and programs are designed, coordinated, promoted and instrumented within the territorial jurisdiction of each municipality; these were called: the Metropolitan Planning Institute of Tijuana, the Municipal Institute for Research and Urban Planning of Mexicali, and the Municipal Institute of Research and Planning of Ensenada.

Finally in 2012, a citizens' initiative is brought in the municipality of Mexicali, a project to perform the tasks of urban planning called "Mexicali, City of Great Vision", which brings together local and state agencies, educational institutions, business and social organizations, by means of a strategic planning tool, Logical Framework Methodology.

\section{Logical framework methodology}

The logical framework methodology is an approach that structures, sets hierarchy, communicates, provides mechanisms for evaluating and monitoring the actions arising from a plan, program or project. Besides the above, the methodology considers as a key element the participation of interest groups throughout the planning process, as well as the commitments they assume for their management [13-15]. The methodology is applied in the Municipal Strategic Development Plan, summarized in six stages as shown in Figure 3: 


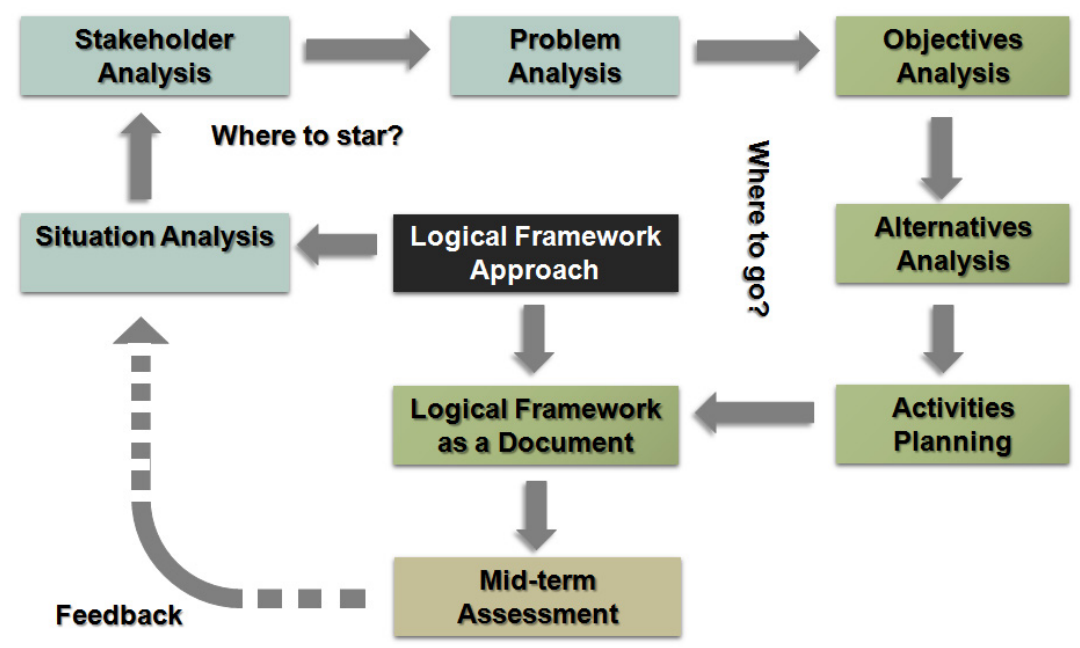

Source: Modified from Metodología del marco lógico para la planificación, el seguimiento y la evaluación de proyectos y programas (Ortegón, Pacheco y Prieto, 2005) and The Logical Framework Approach/ZOPP/OOPP, http://gausa.com/logframe_approach.htm

Figure 3: Logical framework methodology.

First, it starts with the analysis of the situation, describing the conditions framing the problem through documentary sources, expert consultation and databases that record the problems faced by municipal and urban development.

Second, the identification and analysis of individuals, groups and associations that may influence or have influenced in the problems or in their solution, such as civil society, academic and professional organizations, private sector and authorities of different government levels, among others. The purpose of this stage is to present and discuss the interest and expectations that are important for the success of the project.

Third, the participants brainstorm how to set out their views on the issue through discussion until they reach consensus; in the process, a problem is posed and its particulars are specified by the construction of a cause-effect tree.

Fourth, the analysis of objectives, where problems become objectives under the tree format showing the relationship between means and ends.

Fifth, considers the choice of alternatives, but this requires the definition of criteria that will facilitate the evaluation and selection, taking into account different kinds of limitations in order to become a set of objectives that form the project strategy.

Sixth, planning activities, once the objectives, indicators and sources of information are defined. Then, detailed planning is synthesized in the Logical Framework Matrix, which consists in putting on one side of the matrix (columns) the objectives, indicators, means of verification, hypothesis or assumptions, and on the other (lines) the goal, purpose, components and activities. 
Finally, a document is prepared and the project is managed, and then subjected to an interim or medium-term evaluation to obtain feedback and facilitate setting objectives and reorientate actions according to the obstacles of the environment.

\section{Participatory planning: Mexicali, City of Great Vision}

The City of Great Vision project arises as a need for long-term planning to 2050 as set in the 2011 municipal planning meetings, aimed at giving continuity to strategic projects for future municipal administrations. The work was developed through the "Logical Framework" strategic planning tool, which integrated citizen participation in the construction of the project with a bottom-up perspective, and multiple dimensions of development requiring a complex society to respond to local and external environments [16]. In parallel to "City of Great Vision", two other planning instruments were implemented: the Municipal Urban Development Plan and the Metropolitan Strategic Plan; thus the City of Great Vision Project integrated three planning instruments that were proposed in the 2011-2013 Municipal Development Plan.

The territorial planning was conceptualized as a city-region whose boundaries coincide with the municipality of Mexicali, which was in turn divided into three subregions that required the implementation of joint strategies as a municipality, but which also gave differentiated attention to specific problems. Different dimensions of social, economic, environmental and institutional sustainability were worked with through 6 advisory councils that coordinated and integrated the work done by 16 thematic advisory subcommittees that were the basis for the construction of the general project and the specific strategic projects [16].

The planning exercise was organized outside the government and was technically coordinated by the Autonomous University of Baja California; authorities were invited to collaborate together with groups of professionals and civil society, as well as representatives of business associations and academia.

The organization and work management was focused on a pyramid scheme (see figure 4), which consisted of: a) a peer group that formed the basis of shared decisions among the public, private and social sectors, denominated Strategic Development Council; b) a group of 6 coordinating leaders for each of the identified themes for the implementation of the three plans that were to be developed, whose function was the bottom-up work integration and feedback; c) a group of 16 honorary experts invited on the topics to be discussed, representing the basis of work developed with the methodology of logical framework and the identification of strategic actions that justified the detailed proposal of the vision of development, obtained from development studies specialized in urban, economic, social and environmental topics; d) an open public participation had place in various stages of the planning: one, for opinions on the issues and development priorities; and two, for the visualization and selection of scenarios. Both processes performed through the Web.

The planning process lasted nine months of weekly work for the 16 groups with representatives of the various groups of interest. As a complement, a database was 


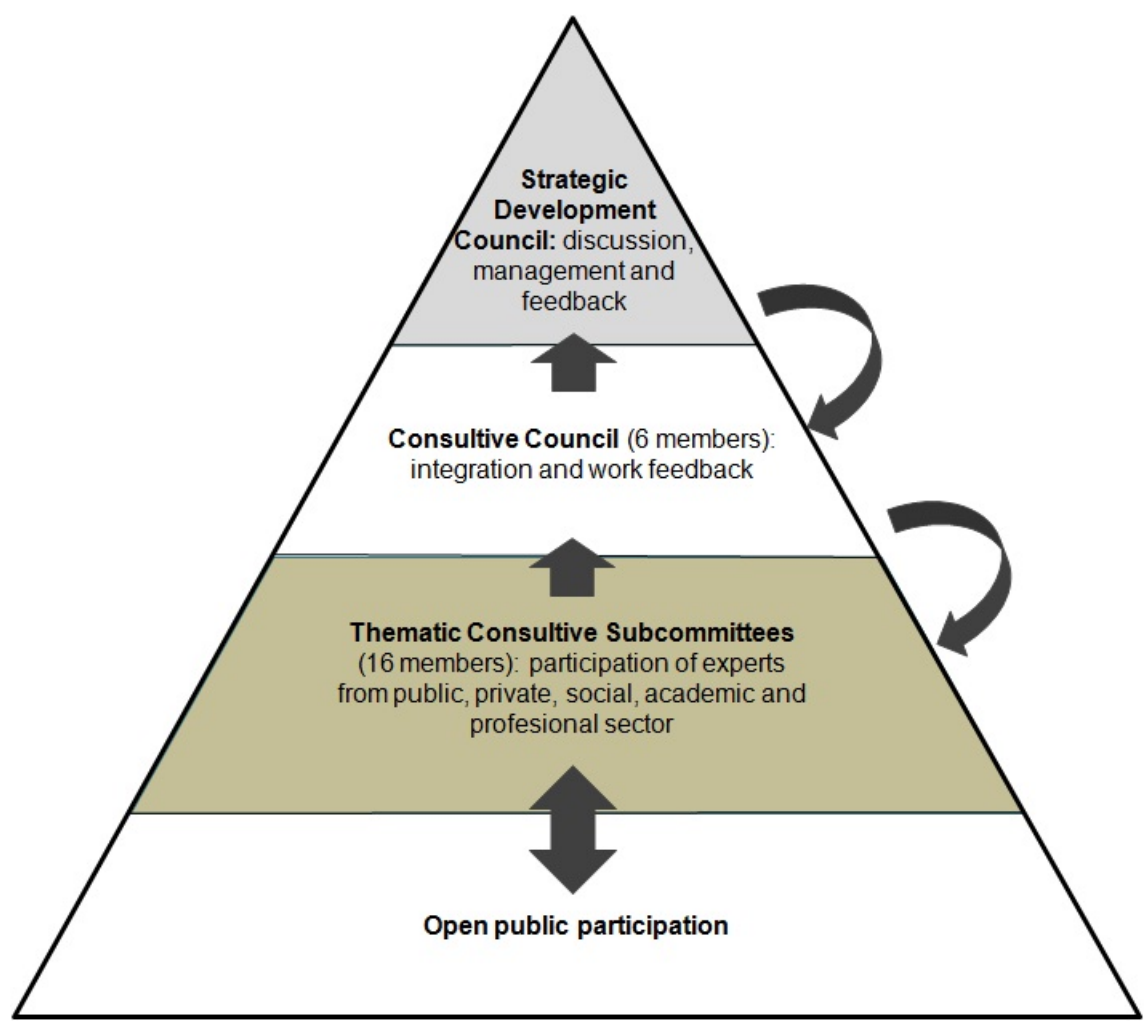

Figure 4: Organizational structure of the project.

integrated and safeguarded, which at the same time gave public access to information and transparency presenting advances, existing research and projects, new proposals, and statistical information and performance indicators.

The implementation of the project required the establishment of commitments with three organizations which logistically and financially supported the project. The Economic Development Council of Mexicali (CDEM, for its initials in Spanish), the Business Coordinating Council, and the Municipal Government through the Mexicali Municipal Planning Committee Development. The technical coordination was in charge of the project leaders and coordinators of the Autonomous University of Baja California and the CDEM. Their responsibility was to check the project's progress and its adjustment to the conditions, features, quality and programming that were established in the terms of reference of the project [16].

The project has an estimated cost of 23 million pesos, and it had a complex management, since various kinds of economic resources had to be gathered together to carry out the activities and events necessary to meet the goals and purposes of the project. $32 \%$ were government funds and the remaining $68 \%$ were altruistic contributions from entrepreneurs and civil society [16]. Contributions 
from the community were raised with voluntary contributions in kind and cash, destined for the supplements required to promote social participation and public consultation. Finally, an invaluable support were the media and journalists who promoted the project through their broadcast media and transmitted newsletters, announcements, interviews, and promotional, facilitating a close contact with the community to the planning groups.

\section{Conclusions}

Considering the evolution of the legal framework at the federal level vis-a-vis the state level, we can highlight three aspects: on one hand, a lag in the process; at the federal level, even though it is where the provisions were created to give greater autonomy to the municipality on urban planning, urban planning has not succeeded to operate as an autonomous public service at the federal level: it has always been associated with other sectors. During the 1976-1982 period, it was merged with public works; in 1982-1992, to ecology; from 1992-2013, to social development; and in the last period, to the countryside and housing sector, thus taking away the power to conduct public policy. Meanwhile at the municipal level, municipal offices dedicated exclusively to urban planning were created as decentralized organs since the early 1990s, finally becoming part of a citizen initiative in the case of the state of Baja California.

Moreover, what has remained at the federal level is the hierarchical top-down structure of the planning system, from federal to municipal level, with no feedback in the reverse direction, as in the definition and creation of metropolitan zones in the country.

Finally, although municipal autonomy has been strengthened in recent periods, it remains subject to federal policies and resources.

From the point of view of planning approaches, the rational-systemic proposal is still in force in Mexico, exercised from the federal centrality (top-down) and characterized by regulation and development funding, but engaged in practical planning with the neoliberal model through the use of strategic methodology. The communication model for application requires policy and institutional changes in order to be operational, since the long-term planning exercise of "City of Great Vision" has seen its implementation hindered by the concentration of decisions in the municipal leaders and the mayor, whose interest is operational and limited to the three-year office term. In this regard, "City of Great Vision" has sought to modify the traditional top-down planning towards a bottom-up proposal.

In that sense, planning has been innovative in its organization, and its exercise by the society has employed a participatory strategic approach with the convergence of various resources for its preparation, using information technologies and communication for queries via social networks, and providing access to the population to both the progress and documents generated online, where the greatest obstacle has been the political management with the new administration to accept the proposal of a plan and projects detached from its political campaign proposals. In this sense, it can be noted that the dynamics of 
changes in the conceptual approach of planning goes at a different speed to the changes that would have to be done institutionally at a municipal level.

Finally, the Logical framework methodology was suitable for the development of the work, although it had its main limitation in time (9 months), as the number of participants in each thematic advisory subcommittee had to be reduced.

\section{References}

[1] G. Sánchez-Luna. "Evolución legislativa de la planeación del desarrollo y la planeación urbana en México," Boletín Mexicano de Derecho Comparado, No. 86, Nueva Serie Año XXIX, pp. 707-731, Mayo-Agosto 1996. [Online]. Available: http://biblio.juridicas.unam.mx/revista/pdf/ DerechoComparado/86/art/art14.pdf, accessed on 12/15/2014.

[2] J. Sobrino, "La urbanización en el México contemporáneo," presented at the Conference Experts Meeting on: Population, Territory and Sustainable Development," CEPAL, Santiago de Chile, Chile, August 16-17, 2011. [Online]. Available: http://www.cepal.org/celade/noticias/paginas/5/ 44305/Jaime Sobrino.pdf, accessed on 12/15/2014.

[3] A. Faludi (publisher), A reader in planning theory. Pergamon, Oxford, 1973.

[4] P. Allmendinger, Planning theory, 2nd. Edition, Palgrave Macmillan, UK, 2002.

[5] L. M. Martínez. (2013). "La planificación en el siglo XXI. Desafíos Institucionales y claves para un nuevo enfoque," presented at the Fifteenth Latin American Conference of Ministers of Civil Service and State Reform. A Short, Medium and Long Term Vision., CLAD-Ministerio de Economía y Finanzas, República de Panamá, Panamá, June 27-28, 2013. [Online]. Available: $\quad$ http://old.clad.org/documentos/otros-documentos/La\%20 Planificacion\%20del\%20Siglo\%20XXI.pdf, accessed on 12/15/ 2014.

[6] J.J. Gutiérrez-Chaparro. "Planeación urbana: crítica y tendencias desde el campo de la teoría. El caso del Estado de México," Bitácora, 24 (1), pp. 1926, 2014. [Online]. Available: http://www.redalyc.org/articulo.oa?id= 74830875003\#, accessed on 12/15/2014.

[7] R. E. Deyle and R.E. Wiedenman, "Collaborative planning by metropolitan planning organization, a test of causal theory," Journal of Planning Education and Research, vol. 34, pp. 257-275, April 8, 2014.

[8] S. Fainstein "New directions in planning theory," Urban Affairs Review, Vol. 35, No. 4, pp. 451-478, 2000. [Online].Available: http://www.chinaup.com:8080/international/case/case/1673.pdf, accessed on 12/15/2014.

[9] A. de las Fuentes-Hernández, Ciudades intermedias en México. Un mecanismo de participación corresponsable. Instituto de Administración Pública, 1st. edition, México, 1994. [Online]. Available: http://biblio. juridicas.unam.mx/libros/libro.htm?l=1684, accessed on 12/15/2014.

[10] G. Méndez, "Adecuación y modernización del marco legal urbano. Ley General de Asentamientos Humanos," Coordinación de Capacitación y Vinculación. Red de Ciudades, Ctsembarq, México, 2014. Available: 
http://www.senado.gob.mx/comisiones/desarrollo_urbano/reu/docs/present acion 250214 1.pdf, accessed on 12/15/2014.

[11] SEDATU, 2015. [Online]. Available: http://www.sedatu.gob.mx/sraweb/, accessed on 12/15/2014.

[12] C. Peña, Metodología para la planificación de áreas verdes urbanas: el caso de Mexicali, Baja California, UABC, Mexicali, 2011.

[13] E. Ortegón, J. F. Pacheco and A. Prieto, Metodología del marco lógico para la planificación, el seguimiento y la evaluación de proyectos y programas, Serie Manuales No. 42, Instituto Latinoamericano y del Caribe de Planificación Económica y Social (ILPES), Santiago de Chile, 2005. [Online]. Available: http://www.cepal.org/es/publicaciones/5607metodologia-del-marco-logico-para-la-planificacion-el-seguimiento-y-laevaluacion, accessed on 12/15/2014.

[14] Team Technologies, Middleburg, Virginia, The Logframe Handbook, a logical framework approach to project cycle management, The World Bank, Washington, 2005. [Online]. Available: http://documents.worldbank.org/ curated/en/2005/01/5846691/logframe-handbook-logical-frameworkapproach-project-cycle-management, accessed on 12/15/2014.

[15] European Integration Office, Guide to the logical framework approach, Republic of Serbia Government European Integration Office, Belgrade, 2011. [Online]. Available: http://www.evropa.gov.rs/Evropa/Show Document.aspx?Type=Home\&Id=525, accessed on 12/15/2014.

[16] Consejo de Desarrollo Económico de Mexicali (CDEM), "Resumen ejecutivo del Plan Estratégico del Municipio de Mexicali 2013-2027," Borrador para consulta. Mexicali, 2014. 